\title{
Characteristics and outcome of severe traumatic brain injuries based on occupational status
}

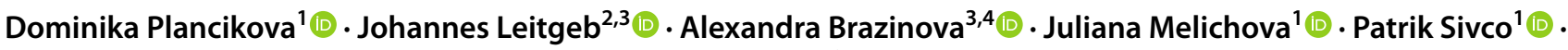

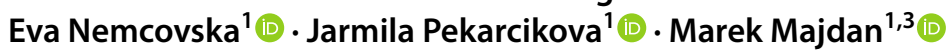

Received: 14 February 2020 / Accepted: 6 April 2020 / Published online: 18 April 2020

(c) The Author(s) 2020

\begin{abstract}
Purpose The association of TBI with socioeconomic characteristics of patients has not been studied extensively. The objective of this study was to analyse the differences in injury characteristics and outcome in TBI patients based on their occupational status.

Methods Data on patients from 13 centres based in Austria, Croatia, Slovakia, Bosnia and Herzegovina, and Macedonia were included in the analysis. Demographic characteristics, injury characteristics, treatment and outcome at various post-injury stages were compared according to occupational status. Logistic regression was used to adjust for the effect of co-variates. ICU mortality, hospital mortality, 6 months mortality, and outcome at 6 months were used as dependent variables.

Results Overall, 886 patients were analysed with a mean age of 45.5 years. High-level falls were most prevalent in the bluecollar group (19\%), most low-level falls occurred in the retired group. Traffic accidents were most common in students. The injuries were most severe in the blue-collar group and students. Highest mortalities and unfavourable outcomes were in the retired, students and white-collar workers had the best outcomes. Compared to retired patients, all groups had higher odds of favourable outcome at 6 months after adjusting for co-variates-OR from 2.2 (95\% CI 1.1-4.6) for entrepreneurs to 3.6 (95\% CI 1.8-7.2) for the blue-collar group.

Conclusion Our paper provides clues pertaining specifically to variations in patterns and outcomes of TBI according to occupational status which can inform prevention and planning of services and can serve to plan priorities for further research.
\end{abstract}

Keywords Traumatic brain injury $\cdot$ Outcome $\cdot$ Occupational status $\cdot$ Epidemiology

\section{Purpose}

Traumatic brain injuries (TBI) have been identified as a major public health problem [1,2]. They are among the most important causes of morbidity and mortality among all age

Marek Majdan

mmajdan@truni.sk

1 Department of Public Health, Institute for Global Health and Epidemiology, Faculty of Health Sciences and Social Work, Trnava University, Hornopotocna 23, 91843 Trnava, Slovakia

2 Department of Orthopedics and Trauma Surgery, Medical University of Vienna, Vienna, Austria

3 International Neurotrauma Research Organisation, Vienna, Austria

4 Faculty of Medicine, Comenius University, Bratislava, Slovakia groups globally, they pose substantial burden on victims, their families and society as a whole [3]. In Europe alone, a recent analysis estimated the hospital-based incidence of TBI at 284 and the mortality at 11 per 100,000 population, which translates to about 1.5 million hospital admissions and 57,000 deaths [1]; an average TBI-related death in Europe was associated with about 24 years of lost life [4]. The global burden of diseases study estimated the global incidence of TBI at 369 per 100,000 which means that an estimated 27.08 million new TBI cases occurred in 2016 [2].

Socioeconomic status (SES) is in general considered to be an important determinant of general morbidity and mortality [5-7]. However, research on the association of SES with outcomes after injuries received only little attention until recent years [8], with studies focusing on TBI being even less common and relatively restricted as to study population, studied outcomes, or severity groups [9-13]. 
Most published studies of associations between SES and injuries focus on paediatric populations with fewer using cohorts of TBI cases from general populations, and their results are conflicting: some studies showed a longer stay in hospital [14], increased 30 day mortality [15], higher risk of injury death [16] and worse non-fatal outcome [8] in more deprived patients; some studies showed associations only in certain subtypes of injuries, such as fighting injuries or sports/recreational injuries [17]; others did not observe any significant differences in outcome based on SES [13, 18, 19].

Previous studies have shown that the context of the injury such as mechanism [20], place of occurrence of the injury [21], age group or social group [22] shows distinctive patterns as to severity, extent and overall outcome of TBI. In a similar manner we hypothesized that TBI will display distinctive patterns of cause, occurrence and outcome based on SES. For our study we have used occupational status as a proxy for SES, as this has been shown to be well approximating SES in general [7].

The objective of this study was to analyse the differences in injury characteristics, treatment, and outcome at various stages post-injury in 886 patients with TBI based on the occupational status of the patient.

\section{Methods}

\section{Data collection and characteristics}

Data on patients from 13 centres were included in the analysis. These data were collected between January 2001 and June 2005 from centres based in Austria (Graz, Klagenfurt, Linz, Salzburg, Vienna), Bosnia and Herzegovina (Sarajevo), Croatia (Osijek, Rijeka, Zagreb), Macedonia (Skopje) and Slovakia (Banska Bystrica, Martin, Michalovce). Data were collected by using the International Traumatic Coma Project [23] database. Data on a total of 1104 patients were available. Of these, data on social status and occupation were available in 886 patients and these were used in this study.

Only patients who sustained severe TBI and survived at least until admission to the intensive care unit (ICU) were included in the dataset-severe TBI was defined as a Glasgow Coma Scale (GCS) score of 8 or less following resuscitation or a GCS score deteriorating to 8 or less within $48 \mathrm{~h}$ of injury.

Detailed data on demographic characteristics (age, sex, education), injury characteristics [mechanism of injury, abbreviated injury scale (AIS) for the region of head, first GCS, Injury Severity Score (ISS), main diagnosis], treatment factors [such as mode of transport, intubation, intracranial pressure (ICP) monitoring, surgeries, days at ICU, length of hospital stay], and outcome at various stages post-injury (ICU mortality, hospital mortality, 6 months mortality, and GOS at 6 months) were available and used in the analyses within this study.

Six-month outcome was recoded from GOS to favourable outcome (GOS of 5 or 4) or unfavourable outcome (GOS of 3 or less). Main diagnosis was stated as contusion, oedema, epidural haemorrhage (EDH), intraventricular haemorrhage (IVH), normal, subarachnoid haemorrhage (SAH), subdural hematoma (SDH) or unknown.

\section{Analysis outline}

The main line of analysis within this study was to compare demographic characteristics, injury characteristics, treatment modalities and outcome at various stages post-injury using occupational status at the time of injury as a stratification variable. For this purpose, six occupational categories were created: blue-collar workers, white-collar workers, entrepreneurs, retired, unemployed and students. First, all available factors were compared across the six groups using univariate analyses-Chi-squared test or Kruskal-Wallis test was used as appropriate.

Subsequently, multivariable logistic regression models were constructed to adjust the association between occupational status and outcomes for the effect of co-variates. Mortality at ICU discharge, mortality at hospital discharge, 6 months mortality and outcome at 6 months post-injury (favourable/unfavourable) were used as dependent variables. Nagelkerke's $R^{2}$ and AUC were calculated to determine the characteristics of the models. $P$ value $<0.05$ was assumed statistically significant. All statistical analyses were performed in R-software [24].

\section{Results}

Demographic characteristics of the patients are presented in Table 1. Overall, 886 patients were included in this analysis. Patients were distributed into the groups quite evenly, retired being the largest $(213,24 \%)$ and entrepreneurs the smallest $(93,10 \%)$. The overall mean age was 45.5 years ( $\mathrm{SD}=21.3)$, entrepreneurs being the oldest of the three economically active groups (i.e. blue- and white-collars, and entrepreneurs). Male sex dominated each group. University-level education was most prevalent in the white-collar and entrepreneur group, almost half of the blue-collar and unemployed group only reached elementary level education. Overall, the distribution of age, sex and education was significantly different among the compared groups.

Data on injury characteristics are presented in Table 2. Injury mechanism distributions were significantly different among the six groups. Low-level falls $(231,26 \%)$, traffic accidents of drivers $(121,14 \%)$ and of pedestrians $(100$, 
Table 1 Demographic characteristics of TBI patients by occupational status

\begin{tabular}{|c|c|c|c|c|c|c|c|c|}
\hline \multirow[t]{2}{*}{ Variable } & \multicolumn{6}{|c|}{ Occupational status } & \multirow[t]{2}{*}{ Total $(n=886)$} & \multirow[t]{2}{*}{$P$ value } \\
\hline & $\begin{array}{l}\text { Blue-collar } \\
(n=168)\end{array}$ & $\begin{array}{l}\text { White-collar } \\
(\mathrm{n}=105)\end{array}$ & $\begin{array}{l}\text { Entrepreneur } \\
(n=93)\end{array}$ & $\begin{array}{l}\text { Retired } \\
(n=213)\end{array}$ & $\begin{array}{l}\text { Unemployed } \\
(n=134)\end{array}$ & $\begin{array}{l}\text { Student } \\
(n=173)\end{array}$ & & \\
\hline Age (mean, SD) & $40.2(12.1)$ & $37.9(13.3)$ & $45(10.8)$ & $70.5(10.3)$ & $53.5(17.5)$ & $18.4(4.8)$ & $45.5(21.3)$ & $<0.001$ \\
\hline $\operatorname{Sex}(n, \%$ male $)$ & $155(92 \%)$ & $80(76 \%)$ & $80(86 \%)$ & $157(74 \%)$ & $81(60 \%)$ & $134(78 \%)$ & $687(78 \%)$ & $<0.001$ \\
\hline \multicolumn{9}{|l|}{ Education $(n, \%)$} \\
\hline University & $4(2 \%)$ & $19(18 \%)$ & $13(14 \%)$ & $15(7 \%)$ & $5(4 \%)$ & $25(14 \%)$ & $81(9 \%)$ & $<0.001$ \\
\hline High school & $45(27 \%)$ & $24(23 \%)$ & $38(41 \%)$ & $33(16 \%)$ & $23(17 \%)$ & $69(40 \%)$ & $232(26 \%)$ & \\
\hline Vocational & $32(19 \%)$ & $58(54 \%)$ & $24(25 \%)$ & $23(11 \%)$ & $7(5 \%)$ & $5(3 \%)$ & $149(17 \%)$ & \\
\hline Elementary & $69(41 \%)$ & $1(1 \%)$ & $14(15 \%)$ & $35(16 \%)$ & $56(42 \%)$ & $66(38 \%)$ & $241(27 \%)$ & \\
\hline Unknown & $18(11 \%)$ & $3(3 \%)$ & $4(4 \%)$ & $107(50 \%)$ & $43(32 \%)$ & $8(5 \%)$ & $183(21 \%)$ & \\
\hline
\end{tabular}

$S D$ standard deviation

$11 \%)$ were the most common in general. High-level falls were most prevalent in the blue-collar group $(32,19 \%)$, whereas, most low-level falls occurred in the retired group. Retired and unemployed had the lowest proportion of traffic-related accidents. Traffic-related accidents (all road users combined) were most common in the student group.

Although the GCS did not differ significantly among the groups, the ISS suggest that the overall injuries were significantly more severe in the blue-collar group, and the student group — compared to all other. The head AIS of the head suggests that head injuries in the entrepreneur and student groups were somewhat less severe, compared to the rest of the groups. SDH were the most common diagnosis across the groups, followed by IVH, contusions, and $\mathrm{EDH}$.

Table 3 presents a summary of treatment modalities. Air transport was significantly more common in the blue- and white-collar groups, compared to the rest. ICP monitoring was least common in the entrepreneur group $(23,25 \%)$, cranial surgeries had to be performed most commonly in white-collar and unemployed group (72, 69\% and 96, 72\%, respectively). White-collar workers had significantly the highest median stay at ICU and at hospital.

The outcome patterns are presented in Table 4. In general, the mortalities at any point in time post-injury were quite high. Highest observed mortalities and unfavourable outcomes were in the retired group, students had the best outcomes, followed by white-collar workers. Blue-collar, white-collar and unemployed patients showed similar patterns. Overall, $45 \%$ of patients died, and $55 \%$ had unfavourable outcome at 6 months post-injury.

In order to analyse the association between occupational status and outcomes, multivariable regression models were constructed, using age, GCS and ISS as adjusting variables (Table 5). Defining the retired group as reference, all groups had higher odds of favourable outcome at 6 months post-injury-OR ranging from 2.2 (95\% CI 1.1-4.6) for the entrepreneur group to 3.6 (95\% CI 1.8-7.2) in the blue-collar group. Unemployed, blue-collar and white-collar workers had significantly higher odds of surviving at hospital discharge and at 6 months, and only unemployed and whitecollar workers had significantly better odds of surviving at ICU discharge, compared to retired.

\section{Discussion}

We conducted a study comparing demographic characteristics of patients, injury characteristics and outcomes of 886 patients with severe TBI after dividing them into six occupational groups. We found that patients displayed different patterns as to injury mechanism, severity and outcome among the compared groups. Occupational group predicted the outcome 6 months post-injury after adjusting for age and injury severity. Short-term outcomes (at ICU discharge and hospital discharge), and mortality at 6 months were less associated with occupational grouping.

To our knowledge, this is the first study analysing occupational status as a possible predictor of TBI patterns and outcomes to date. Therefore, direct comparison with published studies is not possible. Studies previously published on related topics mostly focused on socioeconomic status in general, measured in different ways and using various endpoints in the analyses. The study of Haines et al. [10] used ethnicity, race and insurance status and found that they are associated with differences in mortality, length of stay and discharge to inpatient rehabilitation. Hoofien et al. [11] in their study concluded that socioeconomic variables predicted various aspects of long-term functioning (14 years post-injury). Our study similarly showed varying mortality between the occupational groups as well as length of stay. Contrary to these studies, in a recent analysis by Zuckerman et al. [13], no associations were found between six 
Table 2 Injury mechanism and injury severity characteristics of TBI patients by occupational status

\begin{tabular}{|c|c|c|c|c|c|c|c|c|}
\hline \multirow[t]{2}{*}{ Variable } & \multicolumn{6}{|c|}{ Occupational status } & \multirow[t]{2}{*}{ Total $(n=886)$} & \multirow[t]{2}{*}{$P$ value } \\
\hline & $\begin{array}{l}\text { Blue-collar } \\
(n=168)\end{array}$ & $\begin{array}{l}\text { White-collar } \\
(n=105)\end{array}$ & $\begin{array}{l}\text { Entrepreneur } \\
(n=93)\end{array}$ & $\begin{array}{l}\text { Retired } \\
(n=213)\end{array}$ & $\begin{array}{l}\text { Unemployed } \\
(n=134)\end{array}$ & $\begin{array}{l}\text { Student } \\
(n=173)\end{array}$ & & \\
\hline $\begin{array}{l}\text { Mechanism } \\
(n, \%)\end{array}$ & & & & & & & & $<0.001$ \\
\hline Fall $<3 \mathrm{~m}$ & $31(18 \%)$ & $15(14 \%)$ & $15(16 \%)$ & $97(46 \%)$ & $60(45 \%)$ & $13(8 \%)$ & $231(26 \%)$ & \\
\hline Fall $>3 \mathrm{~m}$ & $32(19 \%)$ & $6(6 \%)$ & $9(10 \%)$ & $11(5 \%)$ & $10(7 \%)$ & $9(5 \%)$ & $77(9 \%)$ & \\
\hline $\begin{array}{l}\text { Traffic } \\
\text { (driver) }\end{array}$ & $27(16 \%)$ & $31(30 \%)$ & $22(24 \%)$ & $4(2 \%)$ & $10(7 \%)$ & $27(16 \%)$ & $121(14 \%)$ & \\
\hline $\begin{array}{l}\text { Traffic (pas- } \\
\text { senger) }\end{array}$ & $6(4 \%)$ & $5(5 \%)$ & $10(11 \%)$ & $11(5 \%)$ & $7(5 \%)$ & $31(18 \%)$ & $70(8 \%)$ & \\
\hline $\begin{array}{l}\text { Traffic } \\
\quad \text { (pedestrian) }\end{array}$ & $10(6 \%)$ & $8(8 \%)$ & $4(4 \%)$ & $31(15 \%)$ & $15(11 \%)$ & $32(18 \%)$ & $100(11 \%)$ & \\
\hline $\begin{array}{l}\text { Traffic (bicy- } \\
\text { cle) }\end{array}$ & $5(3 \%)$ & $6(6 \%)$ & 0 & $13(6 \%)$ & $3(2 \%)$ & $9(5 \%)$ & $36(4 \%)$ & \\
\hline $\begin{array}{l}\text { Traffic } \\
\text { (motorcy- } \\
\text { cle) }\end{array}$ & $19(11 \%)$ & $9(9 \%)$ & $4(4 \%)$ & $6(3 \%)$ & $3(2 \%)$ & $31(18 \%)$ & $72(8 \%)$ & \\
\hline Assault & $9(5 \%)$ & $4(4 \%)$ & $7(8 \%)$ & $4(2 \%)$ & $5(4 \%)$ & $4(2 \%)$ & $33(4 \%)$ & \\
\hline Gunshot & $7(4 \%)$ & $5(5 \%)$ & $5(5 \%)$ & $9(4 \%)$ & $5(4 \%)$ & $8(5 \%)$ & $39(4 \%)$ & \\
\hline Other & $14(8 \%)$ & $12(11 \%)$ & $10(11 \%)$ & $15(7 \%)$ & $6(4 \%)$ & $4(2 \%)$ & $61(7 \%)$ & \\
\hline Unknown & $8(5 \%)$ & $4(4 \%)$ & $7(8 \%)$ & $12(6 \%)$ & $10(7 \%)$ & $5(3 \%)$ & $46(5 \%)$ & \\
\hline $\begin{array}{l}\text { AIS head } \\
\text { (mean, SD) }\end{array}$ & $4.2(0.9)$ & $4.1(1)$ & $3.5(1.2)$ & $4.2(1)$ & $4.1(1.2)$ & $3.9(1.1)$ & $4(1.1)$ & $<0.001$ \\
\hline $\begin{array}{l}\text { First GCS } \\
\quad(\text { mean, SD) }\end{array}$ & $6(2.7)$ & $5.8(2.9)$ & $6.7(3.3)$ & $5.9(2.9)$ & $5.9(2.8)$ & $5.9(2.9)$ & $6(2.9)$ & 0.238 \\
\hline $\begin{array}{l}\text { ISS (mean, } \\
\text { SD) }\end{array}$ & $32.4(16.2)$ & $29.7(15.7)$ & $25.2(14)$ & $26.8(15)$ & $29.4(18.8)$ & $33.9(15.9)$ & $29.8(16.2)$ & $<0.001$ \\
\hline $\begin{array}{l}\text { Main diagnosis } \\
\quad(n, \%)\end{array}$ & & & & & & & & $<0.001$ \\
\hline Contusion & $27(16 \%)$ & $22(21 \%)$ & $18(19 \%)$ & $24(11 \%)$ & $13(10 \%)$ & $28(16 \%)$ & $132(15 \%)$ & \\
\hline Oedema & $3(2 \%)$ & $6(6 \%)$ & $1(1 \%)$ & $1(0 \%)$ & $2(1 \%)$ & $6(3 \%)$ & $19(2 \%)$ & \\
\hline EDH & $34(20 \%)$ & $20(19 \%)$ & $6(6 \%)$ & $12(6 \%)$ & $21(16 \%)$ & $31(18 \%)$ & $124(14 \%)$ & \\
\hline IVH & $23(14 \%)$ & $11(10 \%)$ & $18(19 \%)$ & $32(15 \%)$ & $14(10 \%)$ & $49(28 \%)$ & $147(17 \%)$ & \\
\hline Normal & $6(4 \%)$ & $4(4 \%)$ & $2(2 \%)$ & $3(1 \%)$ & $1(1 \%)$ & $6(3 \%)$ & $22(2 \%)$ & \\
\hline SAH & $8(5 \%)$ & $6(6 \%)$ & $4(4 \%)$ & $10(5 \%)$ & $6(4 \%)$ & $6(3 \%)$ & $40(5 \%)$ & \\
\hline SDH & $62(37 \%)$ & $34(32 \%)$ & $43(46 \%)$ & $129(61 \%)$ & $75(56 \%)$ & $44(25 \%)$ & $387(44 \%)$ & \\
\hline Unknown & $5(3 \%)$ & $2(2 \%)$ & $1(1 \%)$ & $2(1 \%)$ & $2(1 \%)$ & $3(2 \%)$ & $15(2 \%)$ & \\
\hline
\end{tabular}

AIS Abbreviated Injury Scale, $S D$ standard deviation, GCS Glasgow Coma Scale, ISS Injury Severity Score, EDH epidural hematoma, IVH intraventricular haemorrhage, $S A H$ subarachnoid haemorrhage, $S D H$ subdural hematoma

SES variables and symptom duration or missed practice in a cohort of 282 student athletes with concussion.

In more general terms, better SES has been shown to be associated with improved non-fatal outcomes after injury in a recent review of literature conducted by Kruithof et al. [8], Loberg et al. [25] found higher mortality after trauma in patients living in high-poverty neighbourhoods, in African American patients, and in those enrolled in public health insurance. Gilbride et al. [26] found varying patterns of injury types in relation to SES, whereas Amram et al. [27] found that high rates of injuries were predicted by lower education levels of the studied area. McHale and colleagues [15] in their paper concluded that in less severe trauma, patients with low SES have increased risk of 30-day mortality. Thus, there is sufficient evidence supporting the general hypotheses that SES (measured in various ways) is an important factor to consider in the prevention of injuries and TBI and their treatment. 
Table 3 Treatment factors of TBI patients by occupational status

\begin{tabular}{|c|c|c|c|c|c|c|c|c|}
\hline \multirow[t]{2}{*}{ Variable } & \multicolumn{6}{|c|}{ Occupational status } & \multirow[t]{2}{*}{ Total $(n=886)$} & \multirow[t]{2}{*}{$P$ value } \\
\hline & $\begin{array}{l}\text { Blue-collar } \\
(n=168)\end{array}$ & $\begin{array}{l}\text { White- } \\
\text { collar } \\
(n=105)\end{array}$ & $\begin{array}{l}\text { Entrepreneur } \\
(n=93)\end{array}$ & Retired $(n=213)$ & $\begin{array}{l}\text { Unem- } \\
\text { ployed } \\
(n=134)\end{array}$ & $\begin{array}{l}\text { Student } \\
(n=173)\end{array}$ & & \\
\hline $\begin{array}{l}\text { Air transport ( } N \text {, } \\
\% \text { Yes })\end{array}$ & $34(20 \%)$ & $32(30 \%)$ & $11(12 \%)$ & $26(12 \%)$ & $14(10 \%)$ & $11(6 \%)$ & $128(14 \%)$ & $<0.001$ \\
\hline $\begin{array}{l}\text { Intubation }(N, \% \\
\text { Yes) }\end{array}$ & $100(60 \%)$ & $80(76 \%)$ & $53(57 \%)$ & $115(54 \%)$ & $67(50 \%)$ & $82(47 \%)$ & $497(56 \%)$ & $<0.001$ \\
\hline $\begin{array}{l}\text { ICP monitoring } \\
(N, \% \text { Yes })\end{array}$ & $82(49 \%)$ & $63(60 \%)$ & $23(25 \%)$ & $91(43 \%)$ & $64(48 \%)$ & $61(35 \%)$ & $384(43 \%)$ & $<0.001$ \\
\hline $\begin{array}{l}\text { Days ICP moni- } \\
\text { toring (mean, } \\
\text { SD) }\end{array}$ & $8(5.9)$ & $8.8(5.3)$ & $6.2(3.3)$ & $7(5.5)$ & $6.2(4.6)$ & $7.8(5.2)$ & $7.4(5.3)$ & $<0.058$ \\
\hline $\begin{array}{c}\text { Cranial surgery } \\
(N, \% \text { yes })\end{array}$ & $101(60 \%)$ & $72(69 \%)$ & $50(54 \%)$ & $135(63 \%)$ & $96(72 \%)$ & $80(46 \%)$ & $534(60 \%)$ & $<0.01$ \\
\hline $\begin{array}{l}\text { Days at ICU } \\
\text { (median, IQR) }\end{array}$ & $9(4-19)$ & $11(5-26)$ & $5(2-14)$ & $7(3-13)$ & $7(3-12)$ & $7(3-11)$ & $8(3-15)$ & $<0.001$ \\
\hline $\begin{array}{l}\text { Hospital stay } \\
\text { (median, IQR) }\end{array}$ & $17(6-30)$ & $19(6-41)$ & $10(3-28)$ & $8(4-20)$ & $11(3-33)$ & $14(5-25)$ & $12(4-28)$ & $<0.001$ \\
\hline
\end{tabular}

$I C P$ intracranial pressure, $I Q R$ interquartile range, $I C U$ intensive care unit

Table 4 Outcomes of TBI patients by occupational status at different time points post-injury

\begin{tabular}{|c|c|c|c|c|c|c|c|c|}
\hline \multirow[t]{2}{*}{ Variable } & \multicolumn{6}{|c|}{ Occupational status } & \multirow[t]{2}{*}{ Total $(n=886)$} & \multirow[t]{2}{*}{$P$ value } \\
\hline & $\begin{array}{l}\text { Blue-collar } \\
(n=168)\end{array}$ & $\begin{array}{l}\text { White- } \\
\text { collar } \\
(n=105)\end{array}$ & $\begin{array}{l}\text { Entrepreneur } \\
(n=93)\end{array}$ & Retired $(n=213)$ & $\begin{array}{l}\text { Unem- } \\
\text { ployed } \\
(n=134)\end{array}$ & $\begin{array}{l}\text { Student } \\
(n=173)\end{array}$ & & \\
\hline $\begin{array}{l}\text { ICU mortality } \\
(N, \%)\end{array}$ & $59(35 \%)$ & $31(30 \%)$ & $37(40 \%)$ & $123(58 \%)$ & $48(36 \%)$ & $51(29 \%)$ & $349(39 \%)$ & $<0.001$ \\
\hline $\begin{array}{l}\text { Hospital mortal- } \\
\text { ity }(N, \%)\end{array}$ & $62(37 \%)$ & $32(30 \%)$ & $38(41 \%)$ & $139(65 \%)$ & $55(41 \%)$ & $54(31 \%)$ & $380(43 \%)$ & $<0.001$ \\
\hline $\begin{array}{c}6 \text { months mor- } \\
\text { tality }(N, \%)\end{array}$ & $62(37 \%)$ & $35(33 \%)$ & $38(41 \%)$ & $148(69 \%)$ & $58(43 \%)$ & $55(32 \%)$ & $396(45 \%)$ & $<0.001$ \\
\hline $\begin{array}{l}6 \text { months } \\
\text { unfavourable } \\
\text { outcome }(N, \\
\%)\end{array}$ & $80(48 \%)$ & $55(52 \%)$ & $44(47 \%)$ & $170(80 \%)$ & $73(54 \%)$ & $64(37 \%)$ & $486(55 \%)$ & $<0.001$ \\
\hline
\end{tabular}

ICU intensive care unit

\section{Limitations of the study}

We are aware of some limitations pertaining to this study. First, the data comes from different countries and different centres. This on one hand may bias our findings, as demographic characteristics of the populations of the included countries may differ, but it can also in a way be in favour of the generalizability of the findings - as they come from a more diverse population. Secondly, occupational status in our paper serves as a proxy measure of SES. We did not have the opportunity to assess the SES of patients in a more robust way due to non-availability of data. However, occupational characteristics are in general accepted as a good proxy for overall SES and have been used as such previously [7]. 
Table 5 Crude and adjusted odds ratios of the associations of occupational class with outcomes of TBI patients at different time points postinjury

\begin{tabular}{|c|c|c|c|c|c|c|c|c|}
\hline \multirow[t]{2}{*}{ Predictors } & \multicolumn{2}{|c|}{ ICU outcome $($ alive $=1$ ) } & \multicolumn{2}{|c|}{ Hospital outcome (alive $=1$ ) } & \multicolumn{2}{|c|}{6 Months outcome $($ alive $=1)$} & \multicolumn{2}{|c|}{$\begin{array}{l}6 \text { Months outcome (favour- } \\
\text { able }=1 \text { ) }\end{array}$} \\
\hline & OR $(95 \% \mathrm{CI})$ & $P$ value & OR $(95 \% \mathrm{CI})$ & $P$ value & OR $(95 \% \mathrm{CI})$ & $P$ value & OR $(95 \% \mathrm{CI})$ & $P$ value \\
\hline \multicolumn{9}{|l|}{ Occupational status } \\
\hline Retired & 1 & & 1 & & 1 & & 1 & \\
\hline Unemployed & $2.2(1.2-4)$ & $<0.01$ & $2.4(1.3-4.3)$ & $<0.01$ & $2.5(1.4-4.6)$ & $<0.01$ & $3.1(1.7-5.9)$ & $<0.001$ \\
\hline Entrepreneur & $0.8(0.4-1.6)$ & 0.506 & $1.1(0.6-2.3)$ & 0.751 & $1.3(0.7-2.7)$ & 0.442 & $2.2(1.1-4.6)$ & $<0.05$ \\
\hline Blue-collar & $1.7(0.9-3.3)$ & 0.107 & $2.3(1.2-4.4)$ & $<0.05$ & $2.6(1.3-5.1)$ & $<0.01$ & $3.6(1.8-7.2)$ & $<0.001$ \\
\hline White-collar & $2.3(1.1-4.8)$ & $<0.05$ & $3.1(1.5-6.5)$ & $<0.01$ & $3(1.4-6.2)$ & $<0.01$ & $2.6(1.2-5.5)$ & $<0.05$ \\
\hline Student & $1.4(0.6-3.4)$ & 0.494 & $1.7(0.7-4.2)$ & 0.239 & $1.7(0.7-4.2)$ & 0.238 & $3.5(1.4-9.0)$ & $<0.01$ \\
\hline Age & $0.97(0.95-0.98)$ & $<0.001$ & $0.97(0.95-0.98)$ & $<0.001$ & $0.96(0.95-0.98)$ & $<0.001$ & $0.97(0.95-0.98)$ & $<0.001$ \\
\hline First GCS & $1.5(1.4-1.6)$ & $<0.001$ & $1.5(1.4-1.6)$ & $<0.001$ & $1.5(1.4-1.6)$ & $<0.001$ & $1.5(1.4-1.6)$ & $<0.001$ \\
\hline ISS & $0.95(0.94-0.96)$ & $<0.001$ & $0.95(0.94-0.96)$ & $<0.001$ & $0.95(0.94-0.96)$ & $<0.001$ & $0.95(0.94-0.96)$ & $<0.001$ \\
\hline Model parameters & \multicolumn{2}{|c|}{$\begin{array}{l}\text { Nagelkerke } R^{2}: 0.438 \\
\text { AUC: } 0.842\end{array}$} & \multicolumn{2}{|c|}{$\begin{array}{l}\text { Nagelkerke } R^{2}: 0.441 \\
\text { AUC: } 0.841\end{array}$} & \multicolumn{2}{|c|}{$\begin{array}{l}\text { Nagelkerke } R^{2}: 0.455 \\
\text { AUC: } 0.847\end{array}$} & \multicolumn{2}{|c|}{$\begin{array}{l}\text { Nagelkerke } R^{2}: 0.471 \\
\text { AUC: } 0.853\end{array}$} \\
\hline
\end{tabular}

$I C U$ intensive care unit, GCS Glasgow Coma Scale, ISS Injury Severity Score, $O R$ odds ratio, $C I$ confidence interval, $A U C$ area under the curve

\section{Conclusion}

Our paper provides clues pertaining specifically to variations in patterns and outcomes of TBI according to occupational status which can inform prevention and planning of services and can serve to plan priorities for further research.

\footnotetext{
Acknowledgements Professor Walter Mauritz was a founder and president of the International Neurotrauma Research Organisation in Vienna and he devoted his life to improve the outcomes and lives of patients after TBI. He was the principal investigator of the studies leading to the data used in this manuscript. He passed away in may 2015. We would like to dedicate this paper to his memory. We would like to ackowledge the work of Professor Martin Rusnak, co-founder of the International Neurotrauma Research Organisation for his work in managing the studies leading to the data used in this publication. We would like to acknowledge the members of the "Austrian Working Group on Improvement of Early TBI Care" for their work in the design of the study and collection of data used for analyses in this paper. The project was funded jointly by the Austrian Ministry of Health (Contract Oct. 15, 2008) and by the Austrian Worker's Compensation Board (AUVA; FK 11/2008 and FK 11/2010). Data analysis was supported by a grant from AUVA (FK 09/13). INRO was supported by an annual grant from Mrs. Ala Auersperg-Isham and Mr. Ralph Isham and by small donations from various sources. The work of Patrik Sivco on this paper was partly funded by an institutional grant from the Trnava University (Grant Number: 14/TU/2019). The work of Dominika Plancikova on this paper was partly funded by an institutional grant from the Trnava University (Grant Number: 12/TU/2019). The work of Juliana Melichova on this paper was partly funded by an institutional grant from the Trnava University (Grant Number: 9/TU/2019). The funders had no role in study design, data collection and analysis, decision to publish, or preparation of the manuscript.
}

\section{Compliance with ethical standards}

Conflict of interest The authors have no conflicts of interest. Our manuscript has no associated data or the data will not be deposited.

Open Access This article is licensed under a Creative Commons Attribution 4.0 International License, which permits use, sharing, adaptation, distribution and reproduction in any medium or format, as long as you give appropriate credit to the original author(s) and the source, provide a link to the Creative Commons licence, and indicate if changes were made. The images or other third party material in this article are included in the article's Creative Commons licence, unless indicated otherwise in a credit line to the material. If material is not included in the article's Creative Commons licence and your intended use is not permitted by statutory regulation or exceeds the permitted use, you will need to obtain permission directly from the copyright holder. To view a copy of this licence, visit http://creativecommons.org/licenses/by/4.0/.

\section{References}

1. Majdan M, Plancikova D, Brazinova A, Rusnak M, Nieboer D, Feigin V, et al. Epidemiology of traumatic brain injuries in Europe: a cross-sectional analysis. Lancet Public Health. 2016;1(2):e76e83. https://doi.org/10.1016/S2468-2667(16)30017-2.

2. Injury GBDTB, Spinal Cord Injury C. Global, regional, and national burden of traumatic brain injury and spinal cord injury, 1990-2016: a systematic analysis for the Global Burden of Disease Study 2016. Lancet Neurol. 2019;18(1):56-87. https://doi. org/10.1016/S1474-4422(18)30415-0.

3. Maas AIR, Menon DK, Adelson PD, Andelic N, Bell MJ, Belli A, et al. Traumatic brain injury: integrated approaches to improve prevention, clinical care, and research. Lancet Neurol. 2017;16(12):987-1048. https://doi.org/10.1016/S1474 -4422(17)30371-X.

4. Majdan M, Plancikova D, Maas A, Polinder S, Feigin V, Theadom A, et al. Years of life lost due to traumatic brain injury 
in Europe: a cross-sectional analysis of 16 countries. PLoS Med. 2017;14(7):e1002331. https://doi.org/10.1371/journ al.pmed.1002331.

5. Lahelma E, Martikainen P, Laaksonen M, Aittomaki A. Pathways between socioeconomic determinants of health. J Epidemiol Community Health. 2004;58(4):327-32. https://doi. org/10.1136/jech.2003.011148.

6. Mackenbach JP. Health inequalities: Europe in profile. Produced by COI for the Department of Health; 2006.

7. Stringhini S, Carmeli C, Jokela M, Avendano M, Muennig $\mathrm{P}$, Guida F, et al. Socioeconomic status and the $25 \times 25$ risk factors as determinants of premature mortality: a multicohort study and meta-analysis of 1.7 million men and women. Lancet. 2017;389(10075):1229-377. https://doi.org/10.1016/S0140 $-6736(16) 32380-7$.

8. Kruithof N, de Jongh MA, de Munter L, Lansink KW, Polinder $\mathrm{S}$. The effect of socio-economic status on non-fatal outcome after injury: a systematic review. Injury. 2017;48(3):578-90. https://doi.org/10.1016/j.injury.2017.01.013.

9. deGuise E, leBlanc J, Feyz M, Meyer K, Duplantie J, Thomas $\mathrm{H}$, et al. Long-term outcome after severe traumatic brain injury: the McGill interdisciplinary prospective study. J Head Trauma Rehabil. 2008;23(5):294-303. https://doi.org/10.1097/01. HTR.0000336842.53338.f4.

10. Haines KL, Nguyen BP, Vatsaas C, Alger A, Brooks K, Agarwal SK. Socioeconomic status affects outcomes after severitystratified traumatic brain injury. J Surg Res. 2019;235:131-40. https://doi.org/10.1016/j.jss.2018.09.072.

11. Hoofien D, Vakil E, Gilboa A, Donovick PJ, Barak O. Comparison of the predictive power of socio-economic variables, severity of injury and age on long-term outcome of traumatic brain injury: sample-specific variables versus factors as predictors. Brain Inj. 2002;16(1):9-27. https://doi.org/10.1080/02699 050110088227.

12. McQuistion K, Zens T, Jung HS, Beems M, Leverson G, Liepert $\mathrm{A}$, et al. Insurance status and race affect treatment and outcome of traumatic brain injury. J Surg Res. 2016;205(2):261-71. https ://doi.org/10.1016/j.jss.2016.06.087.

13. Zuckerman SL, Zalneraitis BH, Totten DJ, Rubel KE, Kuhn AW, Yengo-Kahn AM, et al. Socioeconomic status and outcomes after sport-related concussion: a preliminary investigation. J Neurosurg Pediatr. 2017;19(6):652-61. https://doi. org/10.3171/2017.1.PEDS16611.

14. Moore L, Cisse B, Batomen Kuimi BL, Stelfox HT, Turgeon AF, Lauzier F, et al. Impact of socio-economic status on hospital length of stay following injury: a multicenter cohort study. BMC Health Serv Res. 2015;15:285. https://doi.org/10.1186/s1291 3-015-0949-2.

15. McHale P, Hungerford D, Taylor-Robinson D, Lawrence T, Astles T, Morton B. Socioeconomic status and 30-day mortality after minor and major trauma: a retrospective analysis of the Trauma Audit and Research Network (TARN) dataset for England. PLoS ONE. 2018;13(12):e0210226. https://doi.org/10.1371/journ al.pone. 0210226 .

16. Laflamme L, Hasselberg M, Burrows S. 20 years of research on socioeconomic inequality and children's-unintentional injuries understanding the cause-specific evidence at hand. Int J Pediatr. 2010. https://doi.org/10.1155/2010/819687.

17. Simpson K, Janssen I, Craig WM, Pickett W. Multilevel analysis of associations between socioeconomic status and injury among Canadian adolescents. J Epidemiol Community Health. 2005;59(12):1072-7. https://doi.org/10.1136/jech.2005.036723.

18. Potter BK, Speechley KN, Koval JJ, Gutmanis IA, Campbell MK, Manuel D. Socioeconomic status and non-fatal injuries among Canadian adolescents: variations across SES and injury measures. BMC Public Health. 2005;5:132. https://doi. org/10.1186/1471-2458-5-132.

19. Sato N, Hagiwara Y, Ishikawa J, Akazawa K. Association of socioeconomic factors and the risk for unintentional injuries among children in Japan: a cross-sectional study. BMJ Open. 2018;8(8):e021621. https://doi.org/10.1136/bmjopen-2018-02162 1 .

20. Majdan M, Mauritz W, Brazinova A, Rusnak M, Leitgeb J, Janciak I, et al. Severity and outcome of traumatic brain injuries (TBI) with different causes of injury. Brain Inj. 2011;25(9):797-805. https://doi.org/10.3109/02699052.2011.581642.

21. Majdan M, Rusnak M, Brazinova A, Mauritz W. Severity, causes and outcomes of traumatic brain injuries occurring at different locations: implications for prevention and public health. Cent Eur J Public Health. 2015;23(2):142-8. https://doi.org/10.21101/cejph .a4025.

22. Majdan M, Mauritz W, Rusnak M, Brazinova A, Rehorcikova $\mathrm{V}$, Leitgeb J. Long-term trends and patterns of fatal traumatic brain injuries in the pediatric and adolescent population of Austria in 1980-2012: analysis of 33 years. J Neurotrauma. 2014;31(11):1046-55. https://doi.org/10.1089/neu.2013.3200.

23. Rusnak M, Janciak I, Majdan M, Wilbacher I, Mauritz W, Australian Severe TBISI. Severe traumatic brain injury in Austria I: introduction to the study. Wien Klin Wochenschr. 2007;119(1-2):23-8. https://doi.org/10.1007/s00508-006-0760-5.

24. RCoreTeam. R: a language and environment for statistical computing. Vienna: R Foundation for Statistical Computing; 2019. https ://www.R-project.org/. Accessed 26 Aug 2019.

25. Loberg JA, Hayward RD, Fessler M, Edhayan E. Associations of race, mechanism of injury, and neighborhood poverty with in-hospital mortality from trauma: a population-based study in the Detroit metropolitan area. Medicine (Baltimore). 2018;97(39):e12606. https://doi.org/10.1097/MD.0000000000 012606 .

26. Gilbride SJ, Wild C, Wilson DR, Svenson LW, Spady DW. Socio-economic status and types of childhood injury in Alberta: a population based study. BMC Pediatr. 2006;6:30. https://doi. org/10.1186/1471-2431-6-30.

27. Amram O, Schuurman N, Pike I, Yanchar NL, Friger M, McBeth $\mathrm{PB}$, et al. Socio economic status and traumatic brain injury amongst pediatric populations: a spatial analysis in greater vancouver. Int J Environ Res Public Health. 2015;12(12):1559460404. https://doi.org/10.3390/ijerph121215009. 